\title{
低温風洞装置を用いた吹雪の実験的研究 \\ Blowing Snow Experiments in a Cold Wind Tunnel
}

根本征樹*

Masaki NEMOTO

1.はじめに

地表面を流れる風は, 地球表層上の様々な物質を移 動・循環させる。降雪時や積雪面上における風は，しば しば吹雪を引き起こし，雪粒子は大気中を輸送される。 強い吹雪は視程を著しく悪化させるとともに，吹きだま りや雪庇を形成し, 交通障害や雪崩発生などの原因とな る。また雪国の建築物では，建物周囲での吹きだまりや 雪の吹き込み, 屋根雪の偏分布荷重など様々な問題が吹 雪により生じる可能性がある。南極水床上や北極域など の寒冷陸域では，吹雪による雪の移動（積雪再配分）が 水循環や質量収支において重要な役割を担っている。

吹雪時における雪粒子の運動形態は，飛砂における砂 粒子の運動と同様に, 転がり (creep), 跳躍 (saltation), 浮遊 (suspension) の3 つ分類される ${ }^{1)}$ 。それぞれの明 確な区別は困難であるが，高さは跳躍が $10 \mathrm{~cm}$ 程度であ るのに対して，浮遊では数十 $\mathrm{m}$ を超える場合もあるとい われている。

吹雪の基礎的なメカニズムの解明や吹雪対策の検討な どにおいて, 風洞実験は有用な研究手法の一つとなって いる。実験の場合, 風速をはじめとする環境条件を任意 に設定した上で現象を観察できる。また模型などを併用 する場合, 対象物の構造や配置について様々なパターン を試験することも野外観測とくらべれば比較的容易であ るほか, 観測よりも試験費用を抑えることも可能である。
さらに，同一条件の実験を繰り返すことが出来るため再 現性の確認も容易である。こうした利点があるため, 野 外観測と並行して風洞実験による吹雪の研究もこれまで 数多く行われてきた。

吹雪風洞実験は，1939年の Finny ${ }^{2)}$ よる，鋸くずや雲 母の粉末を用いた，防雪柵の吹きだまり効果の研究がそ のはじまりとされている。これは吹雪風洞実験のみなら ず，系統だった吹雪研究の最初の例とされている。

吹雪の風洞実験の実際として，現代では，様々な模擬 雪粒子（活性白土，炭酸マグネシウム，ばん砕，クルミ 粉末，おがくずなど）を使うものや，実際の雪を使うも のがある。模擬雪の場合, 常温での実験が可能であるが, 実際の雪を使う場合には，低温室などによる低温環境を 要する，あるいは実験期間が冬期に限られるなどの制約 がある。本稿では実際の雪と，室内風洞を用いた吹雪実 験について, (独) 防災科学技術研究所雪水防災研究セン ター新庄支所の環境実験施設である「雪水防災実験棟

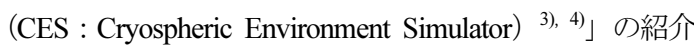
も含めて述べることにする。この場合, 風洞全体が温度 調整可能な実験室（低温室）に設置されていることにな る(低温風洞)。模擬雪を用いた吹雪風洞実験や，冬期低 温時において外気と自然雪を用いた風洞実験については 佐藤 ${ }^{5)}$, 堤 ${ }^{9,}$, 7)の解説にて例が示されているほか, スイ ス国立雪・雪崩研究所 (SLF) の研究例 ${ }^{8)}$, 9)などがあるの

* (独) 防災科学技術研究所雪水防災研究センター新庄支所 主任研究員 Senior Researcher, Shinjo Branch, Snow and Ice Research Center, National Research Institute for Earth Science and Disaster Prevention 
で，そちらを参照されたい。

低温風洞を用いた吹雪実験の最大の特長は，低温下で あるために害際の雪（野外で収集した自然雪や，人工的 に作成した雪）を使用できることである。その場合，模 擬雪実験とは異なり, 粒子の粒径や物性などの違いを考 慮する必要が無い。これは吹雪跳躍層の内部構造の解明 において特に有利である。

\section{2. 吹雪風洞実験}

\section{1 雪水防災実験棟}

雪水防災実験棟 ${ }^{3)}$, 4)では，天然の雪に近い結晶形の雪 を降らすことが可能な人工降雪装置をはじめ, 降雨, 日 射装置が大型低温室 (約 $1500 \mathrm{~m}^{3}$ ) の内部に設置されてお り, 様々な雪水現象を実験室内で再現, 制御することが可能である (図 1)。風洞 装置は吹雪現象の再現を主な目的とし たものであり, 温度制御可能な低温室内 (-30〜+25) に風洞全体が設置されて いる (図 $\mathrm{f} 。$ 表 1 に各装置の諸元をまと めた。

降雪装置は 2 種類あり, 1 つは樹枝状 結晶に近い結晶形の雪（降雪 $\mathrm{A}$, 図 3) を降らすことができる。もう1つは直径 数 $10 \mathrm{~m}$ 程度の水球の集合体からなる雪 (降雪 B, 図 4) を降らすことができる。 降雪 A, B による積雪の初期 密度はそれぞれ $30 \mathrm{~kg} / \mathrm{m}^{3}$ ， $200 \mathrm{~kg} / \mathrm{m}^{3}$ 程度である。いずれ も降雪強度を 5 段階に変更 可能であり, 1 時間あたり最 大 $4 \mathrm{~cm}$ 程度の降雪深を実現 している(図 5)。

日射装置は約 700 個のメ タルハライドランプを用い て日射を模擬するものであ り, 強度を $50 \mathrm{~W} / \mathrm{m}^{2}$ 刻みで 変更可能である。実際の日 射スペクトル分布を忠実に 再現することが望ましいが， ランプの波長域は日射の波 長域を含んではいるものの スペクトル形状は完全には 一致しない。

\section{2 低温風洞}

風洞全体を低温室内に設置した低温風洞の例としては, 北海道大学低温科学研究所の低温風洞施設 10), 12), 12)などが ある（既に廃止）。本稿で紹介寸る雪水防災実験棟の低温 風洞装置 $\left.{ }^{13}\right)$ は, 低温科学研究所の風洞装置を参考に設計 されており, その構造は共通する部分が多い。

風洞装置は密閉型回流式で, 測定部は長さ $14 \mathrm{~m}$, 幅 $1 \mathrm{~m}$, 高さ $1 \mathrm{~m}$, 最大風速は $20 \mathrm{~m} / \mathrm{s}$ である (図 6)。風洞内部にも 空調器が設置されており, きめ細かな温度制御が可能で ある。測定部の底面には深さ $20 \mathrm{~mm}$, 幅 $0.8 \mathrm{~m}$ の溝がつけ られており，雪を敷き詰めて水平一様な雪面を作りやす くするための工夫がなされている（図 7)。

一般に，ある風速のもとで，吹雪が飽和状態（その

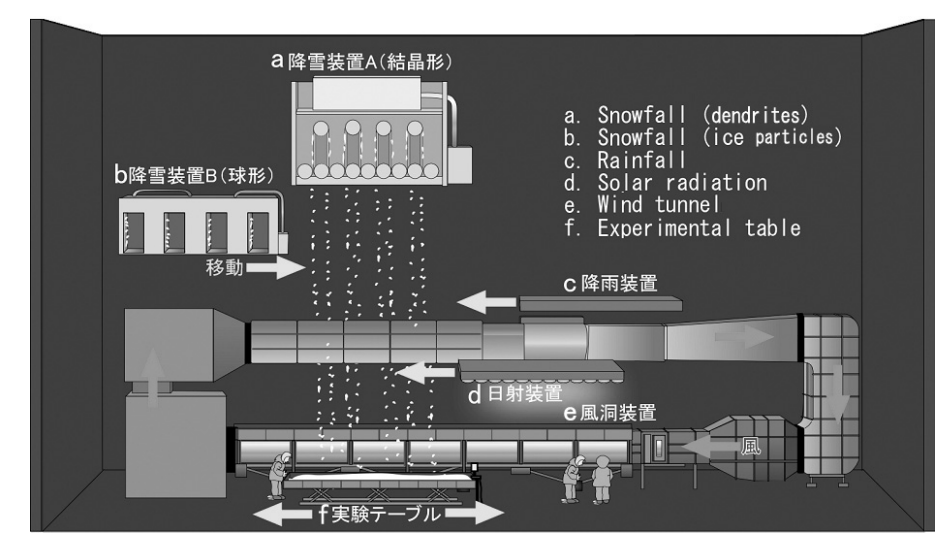

図 1 雪水防災実験棟（CES）の各種装置の配置

表 1 雪水防災実験棟（CES）の主要な装置

\begin{tabular}{|c|c|c|}
\hline 装置 名 & 機 & 様 \\
\hline 降雪装置A & $\begin{array}{l}\text { 樹枝状結晶(径0.5〜 5mm) } \\
\text { の霜を降らせる装置 }\end{array}$ & $\begin{array}{l}\text { 降雪強度: } 0 \text { 1 } 1 \mathrm{~mm} \text { (水換算)/時, } 5 \text { 段階(手·自動) } \\
\text { 運転時間: 連続72時間(最大) } \\
\text { 降雪範囲: } 3 \mathrm{~m} \times 5 \mathrm{~m}\end{array}$ \\
\hline 降雪装置B & $\begin{array}{l}\text { 水球(径約 } 0.025 \mathrm{~mm}) \text { を降ら } \\
\text { せる装置 }\end{array}$ & $\begin{array}{l}\text { 降雪強度: } 0 \text { ～5mm(水換算)/時, } 5 \text { 段階(手·自動) } \\
\text { 運転時間: 連続72時間(最大) } \\
\text { 降雪範囲: } 3 \mathrm{~m} \times 5 \mathrm{~m}\end{array}$ \\
\hline 降雨装置 & 微小水滴を降らせる装置 & $\begin{array}{l}\text { 降雨強度: } 0 \sim 2 \mathrm{~mm} / \text { 時, } 5 \text { 段階(手·自動) } \\
\text { 運転時間: 連続 } 12 \text { 時間(最大) } \\
\text { 降雨範囲: } 3 \mathrm{~m} \times 5 \mathrm{~m}\end{array}$ \\
\hline 日射装置 & $\begin{array}{l}\text { 太陽光のスペクトルに近 } \\
\text { い日射を照射する装置 }\end{array}$ & $\begin{array}{l}\text { 日射強度: } 0 \sim 1000 \mathrm{~W} / \mathrm{m}^{2}, 50 \mathrm{~W} / \mathrm{m}^{2} \text { 毎(手·自動) } \\
\text { 照射範囲: } 3 \mathrm{~m} \times 5 \mathrm{~m} \\
\text { 傾斜角: } 0 \sim 45 \text { 度, 任意(手動) }\end{array}$ \\
\hline 降雪テーブル & $\begin{array}{l}\text { 降雪を積もらせる台, } \\
\text { 昇降·傾斜可能 }\end{array}$ & $\begin{array}{l}\text { 傾斜角: 0 45度, 任意(手動) } \\
\text { 水平寸法: } 3 \mathrm{~m} \times 5 \mathrm{~m} \\
\text { 昇降範囲: } 700 \mathrm{~mm} \text { (手動) }\end{array}$ \\
\hline 風洞装置 & $\begin{array}{l}\text { 任意の速さの風を発生さ } \\
\text { せる装置 }\end{array}$ & $\begin{array}{l}\text { 測定部寸法: 長 }(X) 12 m \times \text { 横 }(Y) 1 m \times \text { 縦 }(Z) 1 \mathrm{~m} \\
\text { 風 速: } 0 \sim 20 \mathrm{~m} / \text { 秒, 任意(手·自動) } \\
\text { 温度調整可能(但し低温実験室と連動) }\end{array}$ \\
\hline 横風発生装置 & $\begin{array}{l}\text { 降雪テーブルA上に風を } \\
\text { 発生させる装置 }\end{array}$ & $\begin{array}{l}\text { 吹出口寸法: 横(Y) } 3 \mathrm{~m} \times \text { 縦(Z) } 0.1 \mathrm{~m} \\
\text { 昇降範囲: } 71 \mathrm{~cm}, \text { 任意(手動) } \\
\text { 風 速: } 0 \sim 10 \mathrm{~m} / \text { 秒, 任意(手動) }\end{array}$ \\
\hline
\end{tabular}




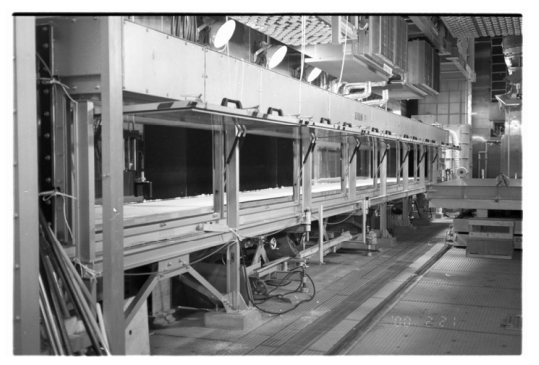

図 2 雪水防災実験棟（CES）の風洞（測定部周辺）

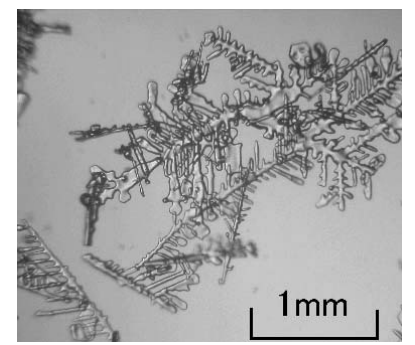

図 3 樹枝状結晶の人工雪 (降雪 $\mathrm{A}$ )

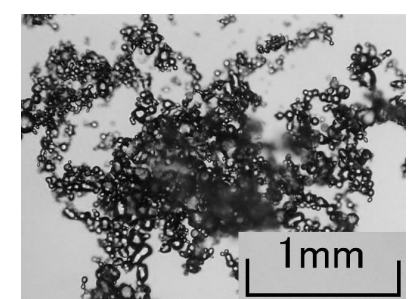

図 4 微小水球からなる人工雪 (降雪 B)

風速で最も強い吹雪の状態）に達するまでには相当な 吹走距離が必要となるが ${ }^{14)}$, 吹雪の発達を促すために 風上から雪粒子を供給寸れば，より短い距離で飽和に近 づく。風洞内一の雪粒子の供給方法は幾つかあるが ${ }^{5)}$, 雪水防災実験棟の風洞では, 測定部の風上端底面に取り 付けられた棒状の吹雪粒子供給装置により，底面の雪 粒子を機械的に削り取り, 気流中に射出している(図 8)。

このタイプの供給装置は風洞内の風の場をほとんど乱 さない。ただし雪面が樹枝状結晶の雪粒子で構成されて いる場合, 粒子同士の絡み合いが顕著であり, 棒状の射

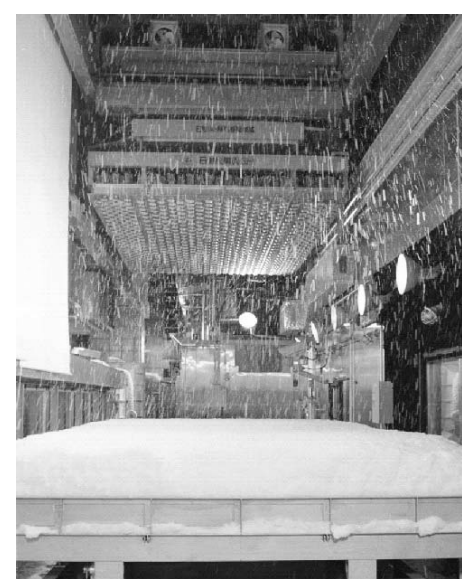

図 5 人工降雪装置（降雪 A）稼動時のようす。降雪 テーブル上に深さ約 $50 \mathrm{~cm}$ の積雪がある

出装置では粒子の安定した供給が困難である。そうした 場合, 回転しているブラシ状の供給装置 (図 9) を用いて, 雪粒子を強制的にかき上げて気流中へ射出させる。なお， 風洞上部には移動式の降雪粒子供給装置があり, 風洞 天板の一部を外してこれを取り付けることにより，そ こから雪片を落下させて風洞内にて降雪・降雪を伴う 吹雪を生じさせることができる（図 10）。ただし落下 中に風によって雪片の選別が行われ，雪片の大きさによ り着地点がずれるため, 一様な降雪を再現できるのは風 洞測定部の限られた領域のみであることに注意しなけれ ばならない。

なお測定域の一部のみであるが，風洞上部にも日射装 置が設置されており，風洞内一の照射が可能である。

後述する吹雪計などのセンサーはトラバース装置に取 り付け，測定部内を 3 次元的に走査することができる。 トラバース装置はマニュアル操作のほか, 専用のプログ ラムに従って自動的に移動可能となっている。

吹雪実験では測定部で舞い上がった吹雪粒子のダ クトへの混入や再循環を防ぐために, 適切な補修装置 が必要となる。補修装置にはサイクロン式やフィルタ 一式などがあり ${ }^{5)}$, 雪水防災実験棟の風洞装置では後

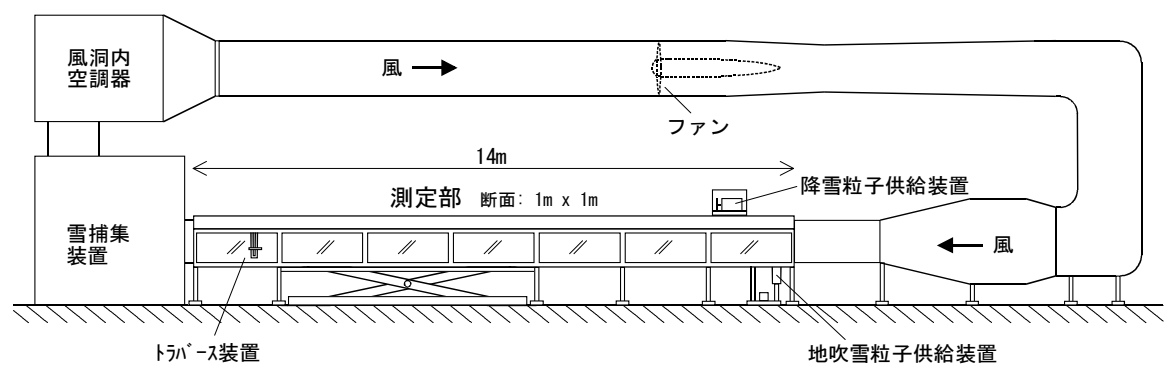

図 6 雪水防災実験棟（CES）の風洞装置（側面図） 


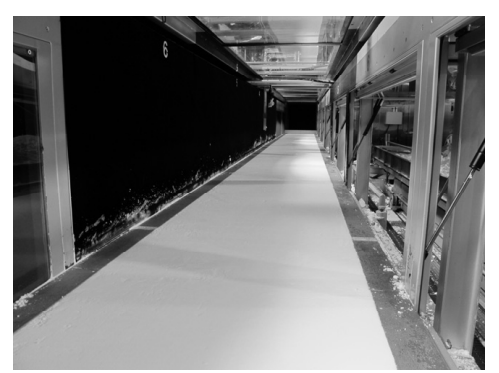

図 7 風洞底面に雪を敷き詰めたようす

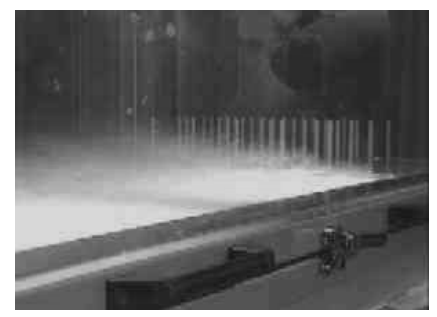

図 8 雪供給装置

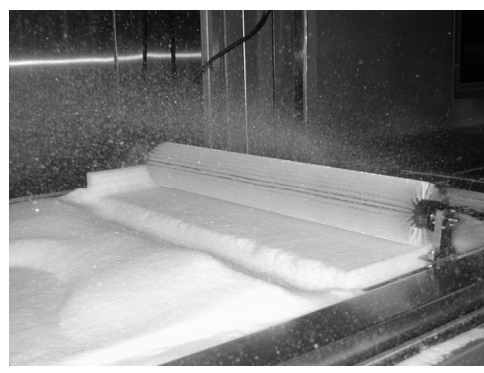

図 9 回転ブラシ式の新雪供給装置

者が用いられている。

風洞内部において, 境界面付近には乱流境界層が形 成される。しかしながら，境界層はあまり厚くなく， 境界面近傍を除くと風の乱れは一般に小さい。このた め, 自然風の乱れの状況を再現するために, 底面にラ フネスブロックなどの粗度要素を置く場合や, 風上に スパイヤーを設置する場合がある。ただし吹雪実験の 場合, 粗度要素周辺に雪粒子が吹きだまる場合もあり, 設置場所などには注意を要する。

\section{3 雪粒子}

既に述べた通り，降った直後の降雪 A は樹枝状結晶に 近い結晶であり, 降雪 $\mathrm{B}$ は微小水球の集合体である。こ れらの雪はそのまま, あるいは一定期間低温下で保存し た後に吹雪実験に用いる。水点下に保って長期保管され た雪は, 自然積雪の場合と同様に，しまり雪へと変化し ている。吹雪実験においてしまり雪を用いる場合, あら かじめ, ふるいなどを用いてほぐし, 個々の粒子間の結

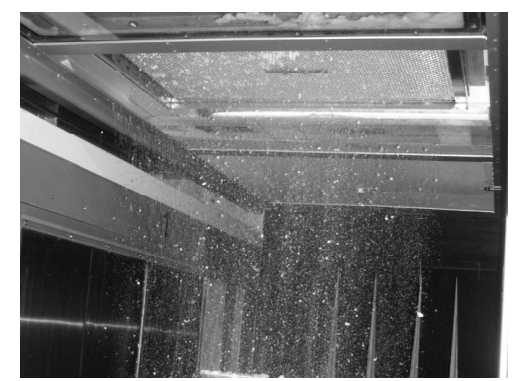

図 10 風洞上面に設置した降雪粒子供給装置

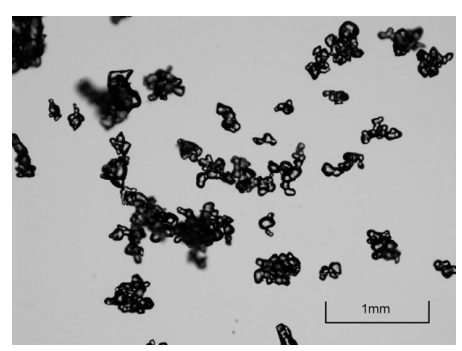

図 11 しまり雪にふるい（1mm メッシュ）をかけて 作成した雪粒子

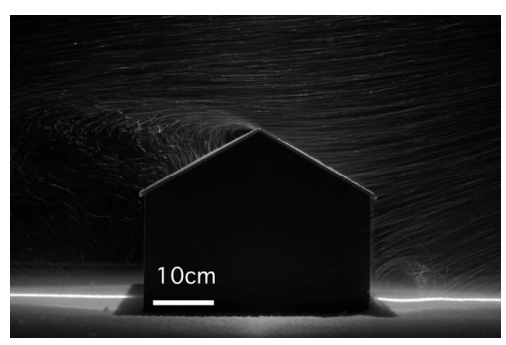

図 12 レーザー光スクリーンで照射して撮影した 吹雪の可視化画像の例 (建物模型周辺)。風 は右から左に吹いている

合を取り除く必要がある（図 11）。

\section{4 吹雪の計測}

吹雪の状態を測定するためには，スノーパーティク ル・カウンター (SPC: Snow Particle Counter) やネット式 の吹雪計などが利用される。前者は空気中を風とともに 移動する吹雪粒子の個数を粒径別に測定できるものであ る。また, 後者の場合, 風はネットを通過するが, 雪粒 は袋の中に捕集される。その重量を測定することで, 吹 雪の質量フラックスを得るものである。これらの測器は 野外観測でも用いられる。吹雪計測の詳細については西

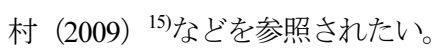

吹きだまりの分布・形状を求めるためには, 積雪の深 さを測定する必要があり，スケールを用いて直接読み取 るか, レーザー距離計などを用いる。後者の場合, トラ バース装置に取り付けることで自動計測も可能である。 
吹雪粒子の運動の可視化のために，光スクリーン（レ ーザー光などをシート状にして風洞内に照射する可視化 装置）を用いることもある（図 12）。

\section{3．吹雪風洞実験の例}

\section{1 吹雪の素過程}

吹雪風洞実験により，吹雪粒子の運動，吹雪の鉛直構 造や発生・発達のメカニズムなどを解明するための基礎 研究が以前から活発に行なわれてきた。風洞実験では特 に，雪面近傍で顕著な吹雪跳躍運動（跳躍層）を取り扱 うことになる。実際の雪粒子を使用する場合, 跳躍運動 のみを対象とする限り相似条件を特に考慮する必要はな い。

吹雪の発生・発達過程において, 跳躍粒子の雪面での 衝突・反発や，衝突により新たな雪粒子が射出されるプ ロセス（スプラッシュ過程）は重要である。そのため, レーザー光を用いた跳躍粒子の可視化（図 13）とそれに よる粒子軌道の統計データ（入射・射出粒子の角度, 速 度や射出粒子数など）の収集・解析が多数試みられてき

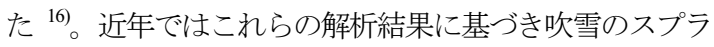
ッシュ関数が導出されており ${ }^{17}$, その成果は吹雪の数值 シミュレーションに反映されるに至っている。

その他, 跳躍層における吹雪の特徵量（吹雪粒子の跳 躍高度, 跳躍距離や吹雪質量フラックスの鉛直分布など) についても様々な実験が実施されている ${ }^{18), 199,20) な と ゙ 。 こ ~}$ れらの実験により, 風速・硬度の増加に伴う跳躍距離の 増加量に関する定量的な知見（図 14）など, 吹雪特徵量 の風速依存性や雪面硬度依存性などが明らかになってき た。

一方，降雪を伴う吹雪の発達過程 ${ }^{21} や ，$ 運動状態にあ る吹雪粒子が昇華蒸発して気流中の水蒸気量が増加寸る 効果 ${ }^{22)}$, 吹雪時において活発に起こっている雪粒子の衝 突や破壊による雪粒子の電荷分離・それによる粒子の帯 電効果 ${ }^{23)}$, 24)などの研究も近年では活発に試みられている。

\section{2 模型実験}

低温風洞では，防雪柵や防雪林などの模型を用いた， 有効な吹雪防止技術の検討なども行われている。防雪柵 には空隙率や構造などが異なるさまざまなタイプがあり， 視程や吹きだまりの抑制効果はそれぞれ異なる。また, 防雪林の防雪効果は, 樹種や樹木の枝葉の茂り具合, さ らには林带幅や樹木の配置などに依存する。これらの複 杂隹な関係を明らかにするため, 防雪柵・防雪林の構造と 吹きだまりの発生位置・規模などとの関係を調べるため

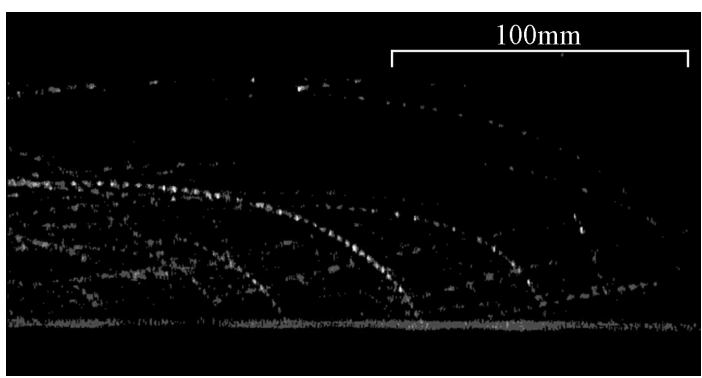

図 13 レーザー光スクリーンで可視化した吹雪粒子 の跳躍運動の軌跡。風は右から左に吹いてい る。シャッターを用いて $1 / 1000$ 秒毎にレーザ 一光を明滅させている。小杉健二氏撮影。

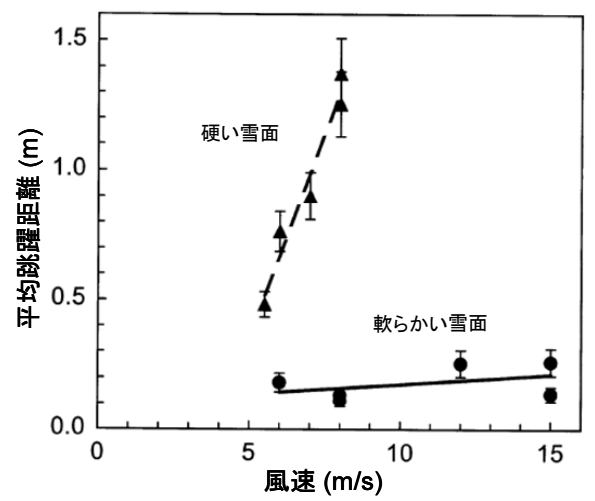

図 14 風洞実験から得られた跳躍粒子の平均跳躍 距離と風速（風洞中心）との関係 ${ }^{18}$

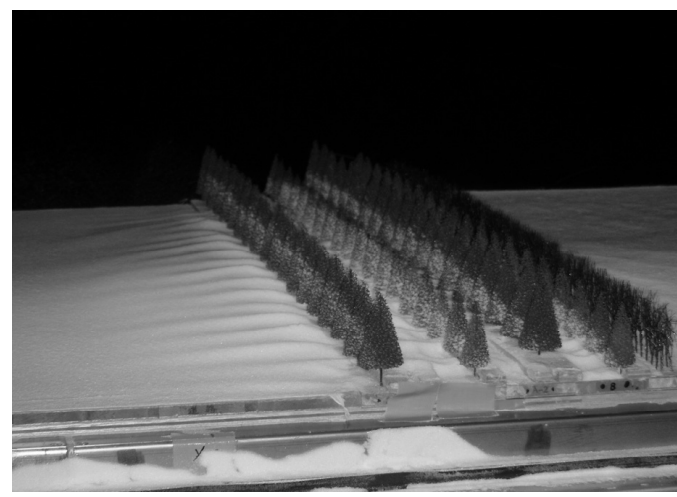

図 15 模型防雪林を用いた吹雪実験実験 ${ }^{26)}$

の実験が数多く行われている ${ }^{25,}$, 26)。図 15 に模型防雪林

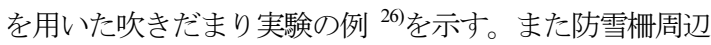

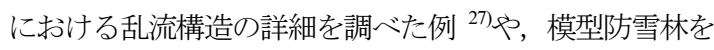
用いた実験結果と野外観測との比較から，防雪林実験に おける適切な相似条件を検討した例 ${ }^{28)}$ もる。なお防雪 柵・防雪林に関する実験の多くは，主流に直交する防雪 施設のみを念頭においた2次元的なものが大半であるが, 
防雪柵の端点付近における風の回り込みの効果に注目し た 3 次元的な実験の例もある ${ }^{29)}$ 。

雪国では，建築構造物周辺に吹雪による吹きだまりが 形成されるため，建築計画においては，その影響を十分 に検討寸る必要がある。こうした場合，建物模型を用い た吹雪実験は有効な手段の一つである。図 16 は立方体の 建物模型周辺の吹きだまり分布の実験例である。建物模 型周辺にウインドスクープと呼ばれる馬蹄状の吹き払い 域とその外側の吹きだまり域が再現されている。さらに 複数の建物があればそれぞれの影響が複合し，より複雑 な吹きだまり分布になると考えられるが，こうした場合 についても, 吹きだまりの複雑な分布を特定する手段と して風洞実験は有効である。なお南極昭和基地の地形模 型上に建物群の模型を配置した吹きだまり実験により, 建物の配置計画や防雪対策が検討された例もある ${ }^{30)}$

雪国では建物の屋根上に雪が積もるが，積雪分布は屋 根形状や風速によって大きく異なる。屋根雪荷重は建築 物の設計や安全確保において重要な課題であるため, 低 温風洞を用いて, 模型屋根の形状・勾配などが屋根雪分 布に及ぼす影響について実験的に検討されている ${ }^{31), 32) な ~}$ ど。図 17 に水平屋根上における堆雪実験の例を示す。 なお，屋根雪荷重の実験では風洞内に降雪を再現させ るため, 風洞天井部の降雪粒子供給装置を用いて雪粒 子を供給することが多い。

\section{4. 今後の課題}

低温風洞による吹雪実験は，低温下で実際の雪を用い ることが可能なため, 特に雪面近傍で顕著な吹雪跳躍層 の物理過程の解明に有用である。 SPC などを用いたこれ までの計測に加えて, PIV (Particle Image Velocimetry) な どの比較的新しい手法に基づく粒子運動の詳細な計測に より, 風と吹雪粒子との相互作用, さらにはその粒径依 存性など, より詳細な運動メカニズムの解明が可能と思 われる。

本稿では詳しく触れなかったが，防雪柵や建物の縮小 模型を用いる実験研究においては, 相似則が大きな問題 となる。吹雪風洞実験において考慮すべき相似条件につ いては, 詳細な実測データに基づいた老川らの検討例 ${ }^{33),}$ 34)などを参照されたい。吹雪実験において考慮すべきも のとしては, 気流の相似や模型の幾何学的相似, さらに は吹雪・吹きだまり形成の継続時間に関する相似など, さまざまである。すべての相似条件を完全に満たした実 験は不可能であり, 実験の目的に応じて適切な相似条件 を取捨選択し，適用寸るのが現実的な手段であろう。そ

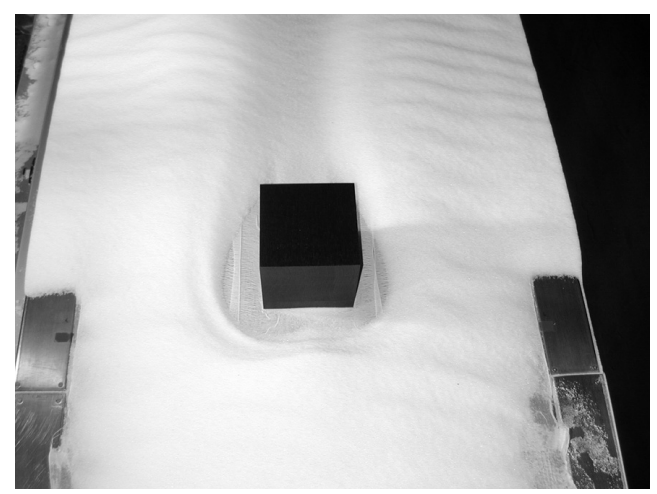

図 16 立方体模型周辺の吹きだまり。風は下から上 に吹いている

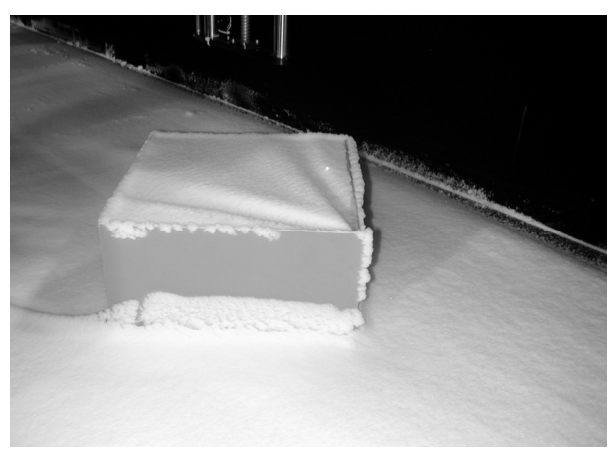

図 17 水平屋根上における堆雪実験（風は右から左 に吹いている)

の際，野外における観測結果と比較しながら，適切な相 似条件を見いだす作業が不可欠となる。

なお，低温風洞では着雪水現象の実験も可能である。 冬期においてしばしば風速計などに着雪水が生じ，機器 の動作不良が起きることがあり，これまでに，その対策

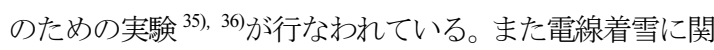
する実験なども行われている。着雪水現象については木 村 (2012) 37)を参照されたい。

参考文献

1) Bagnold, R. A., "The Physics of Blown Sand and Desert Dunes", Methuen, New York, (1941)

2) Finney, E. A., "Snow control on the highways", Michigan Engineering Experiment Station, Michigan State College, Bulletin, 57, pp. 1-60, (1934)

3) Higashiura, M., Abe, O., Sato, T., Numano, N., Sato. A., Yuuki, H. and Kosugi, K., "Preparation of the experimental building for snow and ice disaster prevention", In: Izumi, M., Nakamura, T., Sack, R.D. (Eds.), Snow Engineering: Recent Advances. A. A. Balkema, Rotterdam, Netherlands, pp. 605-608, (1997) 
4）佐藤 威,「雪水防災のための環境実験施設」, 冷凍, 81, pp. 780-787, (2006)

5) 佐藤 威,「吹雪の風洞実験について」, 雪水, $65, \mathrm{pp}$. 279-285, (2003)

6) 堤 拓哉, 「吹雪の風洞実験」, 日本雪工学会誌, $23, p p$. 47-50, (2007)

7) 堤 拓哉,「吹雪風洞」, 日本風工学会誌, $34, p p .36-41$, (2009)

8) Clifton, A., Rüedi, J. D. and Lehning, M., "Snow saltation threshold measurements in a drifting snow wind tunnel", Journal of Glaciology, 52, pp. 585-596, (2006)

9) Guala, M., Manes, C., Clifton, A. and Lehning, M., "On the saltation of fresh snow in a wind tunnel : profile characterization and single particle statistics", Journal of Geophysical Research, 113, F03024, doi:10.1029/2007JF000975, (2008)

10) 小林 俊一,「雪面に働く風の力の測定」, 低温科学, A27, pp. 87-97, (1969)

11) 荒岡 邦明, 前野 紀一，「吹雪における雪粒子の運動 の観察」, 低温科学, A39, pp. 49-54, (1980)

12) Maeno, N., Naruse, R., Nishimura, K., Takei, I., ～Ebinuma, T., Kobayashi, S., Nishimura, H., Kaneda, Y. and Ishida, T., "Wind-tunnel experiments on blowing snow", Annals of Glaciology, 6, pp. 63-67, (1985)

13) 佐藤 威, 小杉 健二, 佐藤 篤司，「雪粒子を用いた風 洞実験による吹雪の研究」, 寒地技術論文・報告集, 15 , pp. 50-54, (1999)

14) Takeuchi, M., "Vertical profile and horizontal increase of drift snow transport", Journal of Glaciology, 26, pp. 481-492, (1980)

15) 西村 浩一，「吹雪の計測」，ながれ，28，pp. 455-460, (2009)

16) 杉浦 幸之助, 前野 紀一，「吹雪における雪粒子の衝 突, 反発, 射出」, 雪水, 65, pp. 241-247, (2003)

17) Sugiura, K., and Maeno, N., "Wind-tunnel measurements of restitution coefficients and ejection number of snow particles in drifting snow: determination of splash functions", Boundary-Layer Meteorology, 95, pp. 123-143, (2000)

18) Kosugi, K., Sato, T. and Sato, A., "Dependence of drifting snow saltation lenghts on snow surface hardness", Cold Regions Science and Technology, 39, pp. 133-139, (2004)

19) Sato, T., Kosugi, K. and Sato, A., "Saltation layer structure of drifting snow observed in wind tunnel", Annals of
Glaciology, 32, pp. 203-208, (2001)

20) 伊藤 優, 大風 翼, 持田 灯, 富永 禎秀, 根本 征樹, 吉野 博, 佐藤 威, 「発達過程の吹雪境界層における 飛雪流量の空間分布に関する風洞実験」, 第 20 回風 工学シンポジウム論文集, 20, pp. 12-17, (2008)

21) Sato, T., Kosugi, K., Mochizuki, S. and Nemoto, M., "Wind speed dependences of fractute and accumulation of snowflakes on snow surface", Cold Regions Science and Technology, 51, pp. 229-239, (2008)

22) Wever, N., Lehning, M., Clifton, A., Rüedi, J.-D., Nishimura, K., Yamaguchi, S., Nemoto, M. and Sato, A., "Verification of moisture budgets during drifting snow conditions in a cold wind tunnel", Water Resources Research, 45, doi:10.1029/2008WR007522, (2009)

23) Omiya, S., Sato, A., Kosugi, K. and Mochizuki, S., "Estimation of the electrostatic charge of individual blowing-snow particles by wind tunnel experiment", Annals of Glaciology, 52, pp. 148-152, (2011)

24) 大宮 哲, 佐藤 篤司，「吹雪粒子の帯電と跳躍回数に 関する風洞実験」，雪氷, 73, pp. 205-212, (2011)

25) 佐藤 威, Gurer, I., 小杉 健二, 佐藤 篤司, 「非平均 状態にある防雪体風下の吹き溜まりに関する風洞実 験」，寒地技術論文，報告集，18,pp. 343-348, (2002)

26) 山田 毅, 伊東 靖彦, 松澤 勝, 根本 征樹, 小杉 健二, 望月 重人, 齋藤 佳彦, 「風洞実験による防雪林の樹 木形態と防雪効果の関係について一その $3 」$, 北海道 の雪水, 27, pp. 73-76, (2008)

27) Keylock, C. J., Nishimura, K., Nemoto, M. and Ito, Y., “The flow structure in the wake of a fractal fence and the absence of an "inertial regime", Environmental Fluid Mechanics, in printing

28) 鳥田 宏行, 根本 征樹, 西村 浩一, 佐藤 威, 「防雪林 に関する野外観測と風洞実験の比較」，雪氷，66, pp. 377-387, (2004)

29) Takeuchi,Y., Kobayashi, S., Sato, T., Izumi, K., Kosugi, K., Wang, X., Zhang, J. and Peng, Y., "The effect of wind direction on drift control by snow fences", Annals of Glaciology, 32,pp. 159-162, (2001)

30) 大久保 紀彦, 遠藤 悠介, 半貫 敏夫, 鮎川 勝, 高橋 弘樹, 阿部 修，「南極昭和基地居住区のスノウドリフ 卜対策に関する風洞実験」，寒地技術論文・報告集, 18 , pp. 335-342, (2002)

31) 桜井 修次, 真田 朋幸, 阿部 修, 城 攻, 「人工雪を用 いた降雪風洞実験および屋根面の変動風圧分布特性 
に基づく屋根雪分布形状の推定に関する開発研究」, 日本建築学会構造系論文集, 620,pp.9-16,(2007)

32) 桜井 修次, 阿部 修, 城 攻, 「風洞実験手法による屋 根雪の偏分布形状に及ぼす屋根面の風圧分布特性の 影響に関するケーススタデイ」, 日本建築学会構造系 論文集, 637,pp. 451-458, (2009)

33) 老川 進, 苫米地 司, 石原 猛, 「建物近傍の雪吹き だまりの風洞相似則に関する考察, 日本雪工学会誌, 23, pp. 133-152, (2007)

34) 老川進, 苫米地 司, 石原猛, 「建物近傍における雪 吹きだまりの風洞相似則」，ながれ, 26, pp. 319-324, (2007)

35) 木村 茂雄, 森川 浩司, 佐藤 威, 山岸陽一, 小島 徹 也，「寒冷環境下での風力利用に関わる風速計測の問 題」，寒地技術論文・報告集, 25, pp. 57-61,(2009)

36) 木村茂雄, 森川浩司, 佐藤 威, 山岸 陽一, 小島 徹 也, 吉岡 貴文, 川上 和樹,「超音波風速計の異常計測 の発生機構に関する研究」, 寒地技術論文・報告集, 26, pp. 33-37, (2010)

37) 木村 茂雄, 「風観測に及ぼす着水雪の影響」, 日本風 工学会誌, 130,pp. 17-26, (2012) 